\title{
Perbandingan: Kualitas Sumber Daya Manusia (SDM) Pariwisata Pra Dan Masa Pandemi Covid-19 di Objek Wisata Pantai Pangandaran
}

\author{
Arga Sutrisna*, Ari Arisman \\ Universitas Perjuangan \\ Jl. PETA No. 177 Kota Tasikmalaya \\ *Correspondence email: argasutrisna @unper.ac.id
}

\begin{abstract}
Abstrak. Tujuan dari penelitian ini untuk menganalisis perbandingan Kualitas SDM Pariwisata di Objek Wisata Pantai Pangandaran pada masa dan sebelum Pandemi Covid-19 berdasarkan kecerdasan emosional dan kecerdasan intelektual. Metode dalam penelitian ini adalah Penelitian Komparatif dengan pendekatan Kuantitatif. Kesimpulan dari penelitian ini adalah terdapat Perbedaan Kualitas SDM Pariwisata pada masa dan sebelum pandemi covid-19 di Objek Wisata Pantai berdasarkan kecerdasan emosional dan kecerdasan intelektual, sehingga dapat disimpulkan terdapat perbedaan Kualitas Sumber Daya Manusia Pariwisata pada masa dan sebelum pandemi covid-19 berdasarkan Kecerdasan Emosional (EQ) Dan Kecerdasan Intelektual (IQ).
\end{abstract}

Kata kunci: Kecerdasan emosional (EQ); Kecerdasan intelektual (IQ); Sumber daya manusia pariwisata.

Abstract. The purpose of this study was to analyze the comparison of the Quality of Tourism Human Resources in Pangandaran Beach Attraction in the period and before the Covid-19 Pandemic based on emotional intelligence and intellectual intelligence. The method in this research is Comparative Research with a Quantitative approach. The conclusion of this study is that there are Differences in the Quality of Tourism Human Resources in the period and before the covid-19 pandemic in Coastal Attractions based on emotional intelligence and intellectual intelligence, so it can be concluded that there are differences in the Quality of Tourism Human Resources in the period and before the covid-19 pandemic based on Emotional Intelligence (EQ) and Intellectual Intelligence $(I Q)$.

Keywords: Emotional intelligence (EQ); Intellectual intelligence (IQ); Human resources tourism

\section{PENDAHULUAN}

Pandemi Covid-19 menjadi sesuatu yang sangat luar bisa, karena tidak ada yang siap menghadapi Pandemi ini. Semua Negara berusaha mengatasi Pandemi Covid-19, hal yang sama di lakukan Indonesia untuk mengatasi nya. Dari mulai pemberlakuan Pembatasan Sosial Berskala Basar (PSBB) hingga Pemberlakuan Pembatasan Kegiatan Masyarakat atau disingkat dengan PPKM. Langkah-langkah pemerintah Indonesia dalam menangani Pendemi Covid-19 ini tentunya berakibat pada aktivitas masyarakat yang berkurang sehingga mobilitas manusia bepergian ke objek wisata semakin berkurang juga. Pengurangan kunjungan wisatawan ke Objek Wisata mempengaruhi ketahanan hidup masyarakat yang menggantungkan hidupnya dari kedatangan para Wisatawan.

\section{PERKEMBANGAN PARIWISATA PROVINSI JAWA BARAT MARET 2020}

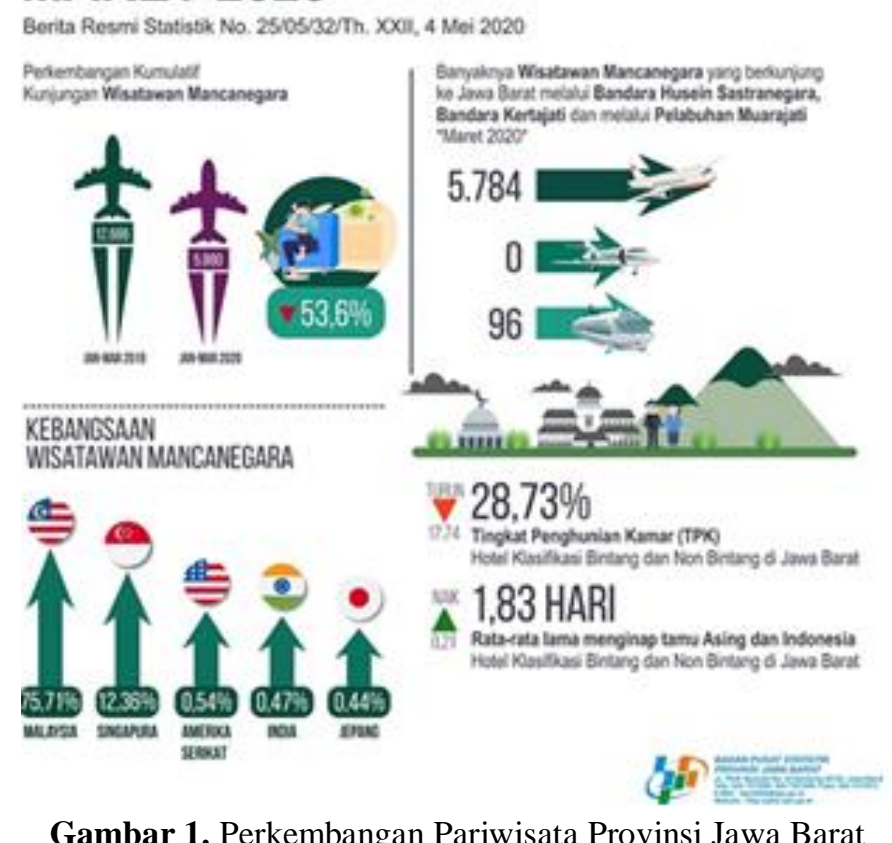

Gambar 1. Perkembangan Pariwisata Provinsi Jawa Barat 2020

Perkembangan Periwisata Provinsi Jawa Barat Maret 2020 terlihat terjadi penurunan jumlah wisatawan yang datang ke Jawa Barat dibandingkan Maret 2019. 


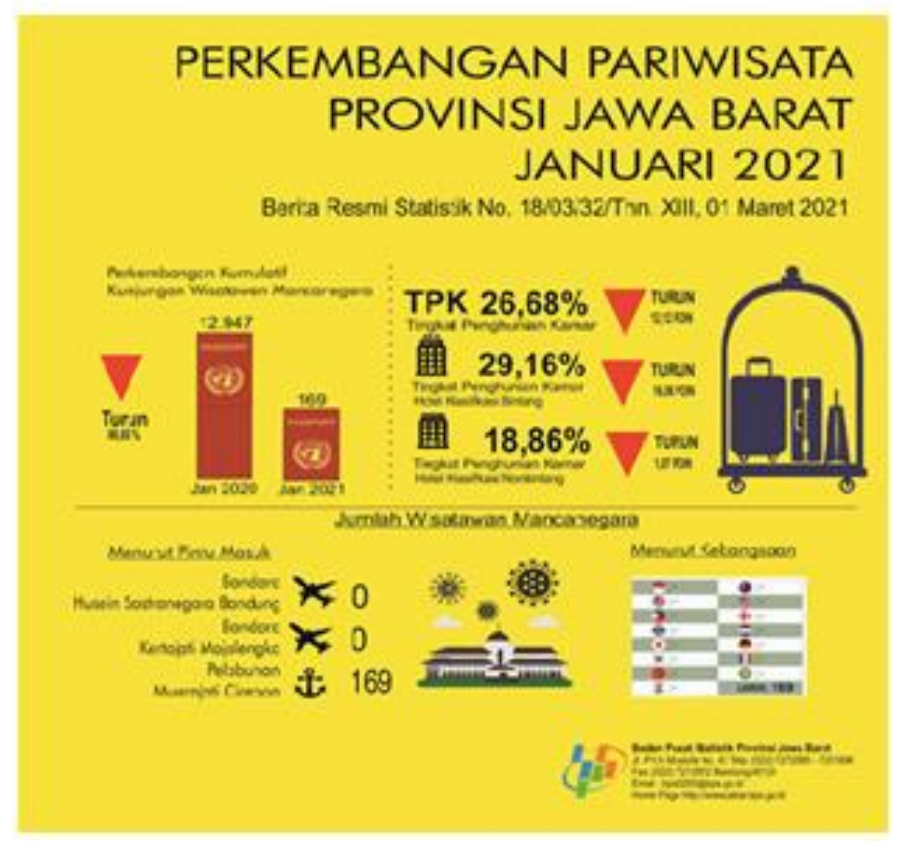

Gambar 2. Perkembangan Pariwisata Provinsi Jawa Barat Januari 2021

Perkembangan Pariwisata Provinsi Jawa Barat januari 2021 masih mengalami terus penurunan setelah pada Maret 2020, tingkat hunian kamar saja turun dari $28,73 \%$ menjadi $26,68 \%$.

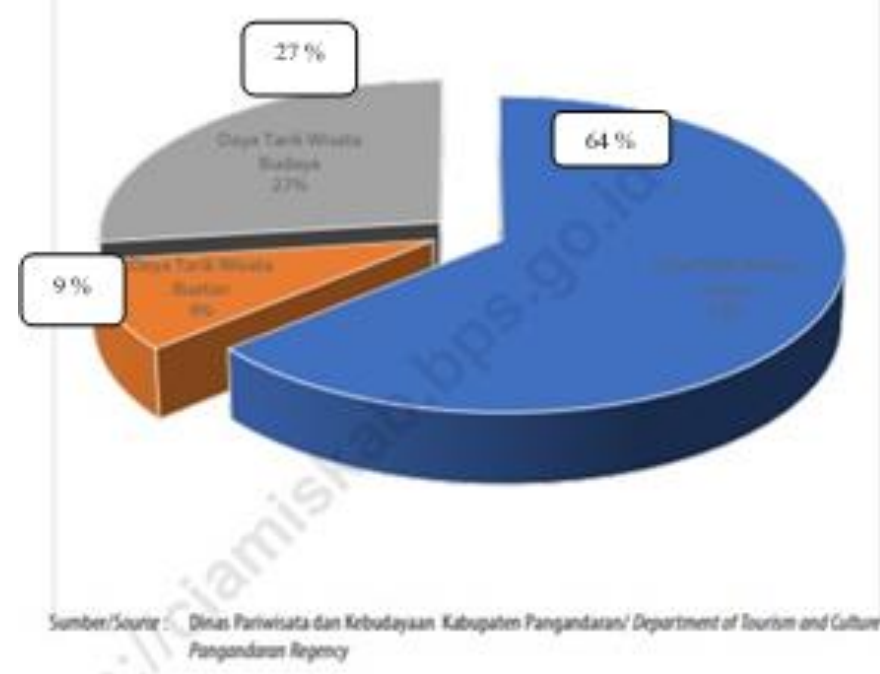

Gambar 3. Persentase Daya Tarik Wisata Menurut Jenisnya, 2020

Daya Tarik Wisatawan pada Wisata Alam di Pangandaran sangat besar yaitu 64\% dari jumlah keseluruhan, dimana Objek Pantai PAngandaran menjadi Wisata Alam terbesar yang mendatangkan Wisatawan. Dengan mulai banyak nya Wisatawan yang datang diharapkan kualitas SDM Pariwisata di Objek pantai pangandaran semakin bisa bersaing dengan tempat/Wisata lainya. Dari hal ini perlu kiranya penulis melakukan penelitian lanjutan yang sebelumnya sudah dilakukan sebelum Pandemi Covid-19 untuk membandingkan ada tidak nya perubahan yang terjadi di Manajemen Sumber Daya Manusia Pariwisata sebagai efek pandemic covid-19.

\section{Kecerdasan Emosional (EQ)}

Kecerdasan emosional adalah kemampuan seperti kemampuan untuk memotivasi diri sendiri dan bertahan menghadapi frustasi, mengendalikan dorongan hati dan tidak melebih-lebikan kesenangan, mengatur suasana hati dan menjaga agar beban stress tidak melumpuhkan kemampuan berfikir, berempati, dan berdoa. Daniel Goleman (2016)

EQ memiliki 5 dimensi menurut Salovey dalam Daniel Goleman (2016)

1. Mengenali emosi sendiri

2. Mengelola emosi

3. Memotivasi diri sendiri

4. Mengenali emosi orang lain

5. Membina hubungan

Ada beberapa faktor yang mempengaruhi kecerdasan emosi individu menurut Goleman (2005), yaitu :

\section{Lingkungan keluarga}

Kehidupan keluarga merupakan sekolah pertama dalam mempelajari emosi. Peran serta orang tua sangat dibutuhkan karena orang tua adalah subyek pertama yang perilakunyadiidentifikasi, diinternalisasi yang pada akhirnya akan menjadi bagian dari kepribadian anak.

2. Lingkungan non keluarga

Dalam hal ini adalah lingkungan masyarakat dan lingkungan penduduk. Kecerdasan emosi ini berkembang sejalan dengan perkembangan fisik dan mental anak. Pembelajaran ini biasanya ditunjukkan dalam aktivitas bermain anak seperti bermain peran. Anak berperan sebagai individu di luar dirinya dengan emosi yang menyertainya sehingga anak akan mulai belajar mengerti keadaan orang lain. Pengembangan kecerdasan emosi dapat ditingkatkan melalui berbagai macam bentuk pelatihan diantaranya adalah pelatihan asertivitas, empati dan masih banyak lagi bentuk pelatihan yang lainnya.

\section{Kemampuan Intelektual (IQ)}

Kecerdasan intelektual lazim disebut dengan inteligensi. Istilah ini dipopulerkan kembali pertama kali oleh Francis Galton, seorang ilmuwan dan ahli matematika yang terkemuka dari Inggris. Sholeh dan Wahab (2004) menyebutkan Kecerdasan Intelektual adalah kemampuan yang dibawa sejak lahir yang memungkinkan seseorang berbuat sesuatu dengan cara tertentu, atau pengetahuan yang bersifat umum untuk mengadakan penyesuaian terhadap suatu situasi atau masalah. Menurut Moustafa dan Miller (2003) dimensi yang membentuk kamampuan intelektual yaitu meliputi: 1) Kecerdasan numeric yaitu kecerdasan dalam 
menangkap serta mengelola angka dan data; 2) Pemahaman verbal yaitu kecerdasan yang berkaitan dengan kepandaian membaca, menulis dan berbicara; 3) Kecepatan Persepsi yaitu kemampuan mengidentifikasi kemiripan dan perbedan visual dengan cepat dan akurat; 4) Penalaran induktif yaitu kemampuan mengidentifikasi urutan logis dalam sebuah masalah dan memecahkan masalah itu; 5) Penalaran deduktif yaitu kemampuan menggunkan logika dan menilai implikasi dari sebuah argumen.; 6) Visualisasi spasial yaitu kemampuan membayangkan bagaimana sebuah objek akan terlihat bila posisi dalam ruangan diubah; 7) Ingatan yang baik yaitu kemampuan membayangkan bagaimana sebuah objek akan terlihat bila posisi dalam ruangan diubah.

Spearman mengelompokan inteligensi ke dalam dua kategori. Kategori yang pertama adalah g faktor atau biasa disebut dengan kemampuan kognitif yang dimiliki individu secara umum, misalnya kemampuan mengingat dan berpikir. Kategori yang kedua disebut dengan $\mathrm{s}$ faktor yaitu merupakan kemampuan khusus yang dimiliki individu, Eysenck (1981).

\section{Kualitas Sumber Daya Manusia (SDM) Pariwisata}

Kualitas sumber daya manusia terdiri atas dua suku kata meliputi kata kualitas yang secara umum merupakan tingkat baik buruknya atau taraf atau derajat sesuatu. Adapun pengertian kualitas menurut Sedarmayanti (2012), mengemukakan bahwa "Kualitas merupakan suatu ukuran yang menyatakan seberapa jauh telah dipenuhi berbagai persyaratan, spesifikasi, dan harapan"

Pengembangan pengetahuan tenaga kerja ditekankan pada 3 hal pokok: (Rony Ika Setiawan, 2016) pertama, terdapat pengembangan pengetahuan tentang tata cara pelayanan yang berkaitan dengan bervariasinya kegiatan pariwisata, misalnya pelayanan di hotel, berbeda dengan pelayanan di tempat rekreasi atau dalam perjalanan wisata; kedua, terdapat pengembangan pengetahuan tentang peralatan dan perlengkapan yang diperlukan dalam bidang pelayanan; ketiga, terdapat pengembangan SDM yang berkaitan dengan pengembangan sikap, perilaku, sopan santun, dan sebagainya.
Ketiga hal tersebut setiap saat selalu berubah dan mengarah pada kemajuan, sehingga ketiganya harus selalu ditingkatkan khususnya melalui pendidikan, yang juga akan mempengaruhi daya serap industri. (Rony Ika Setiawan, 2016)

Pengertian kualitas kerja karyawan dapat diartikan kualitas kerja yang mengacu pada kualitas sumber daya manusia seperti pengetahuan, keterampilan dan kemampuan yang dimiliki seorang karyawan. (Matutina, 2001)

Sumber daya manusia yang memiliki kualitas yang tinggi adalah sumber daya manusia yang mampu menciptakan bukan saja nilai komparatif tetapi juga nilai kompetitif, dan inovatif dengan menggunakan energi seperti intelligance, creativity, dan imagination. (Rachmawati, 2007)

Kualitas kerja mengikuti kualitas sumber daya manusia itu sendiri, dimana kualitas sumber daya manusia mengacu pada : (Matutina, 2001)

1. Pengetahuan (Knowledge) merupakan kemampuan yang dimiliki karyawan yang lebih berorientasi pada intelejensi dan daya fikir serta penguasaan ilmu yang luas yang dimiliki karyawan.

2. Keterampilan (Skill), merupakan kemampuan dan penguasaan teknis operasional di bidang tertentu yang dimiliki karyawan.

3. Abilities merupakan kemampuan yang terbentuk dari sejumlah kompetensi yang dimiliki seorang karyawan yang mencakup loyalitas, kedisiplinan, kerjasama dan tanggung jawab

\section{METODE}

Metode yang digunakan dalam penelitian ini adalah Penelitian Komparatif dengan pendekatan Kuantitatif.

\section{HASIL DAN PEMBAHASAN}

Hasil Kualitas SDM Pariwisata Pra dan Masa Pandemi Covid-19 di Objek Wisata Pantai Pangandaran adalah sebagai berikut :

\section{Pra atau Sebelum Pandemi Covid-19}

\begin{tabular}{|c|c|c|c|c|c|}
\hline \multicolumn{6}{|c|}{$\begin{array}{l}\text { Tabel 1. Hasil SPSS } \\
\text { Model Summary }^{\mathbf{b}}\end{array}$} \\
\hline Model & $\mathrm{R}$ & R Square & $\begin{array}{l}\text { Adjusted R } \\
\text { Square }\end{array}$ & $\begin{array}{l}\text { Std. Error of the } \\
\text { Estimate }\end{array}$ & $\begin{array}{l}\text { Durbin- } \\
\text { Watson }\end{array}$ \\
\hline 1 & $.649^{\mathrm{a}}$ & .421 & .409 & .444292 & 2.047 \\
\hline
\end{tabular}


Arga Sutrisna dan Ari Arisman, Perbandingan: Kualitas Sumber Daya Manusia (SDM) Pariwisata Pra dan Masa Pandemi Covid-19 di Objek Wisata Pantai Pangandaran

\begin{tabular}{|c|c|c|c|c|c|c|}
\hline \multicolumn{7}{|c|}{ ANOVA $^{a}$} \\
\hline & Model & Sum of Squares & df & Mean Square & $\mathrm{F}$ & Sig. \\
\hline \multirow[t]{3}{*}{1} & Regression & 13.945 & 2 & 6.973 & 35.324 & $.000^{\mathrm{b}}$ \\
\hline & Residual & 19.147 & 97 & .197 & & \\
\hline & Total & 33.093 & 99 & & & \\
\hline
\end{tabular}

a. Dependent Variable: KUALITAS MSDM

b. Predictors: (Constant), IQ, EQ

\begin{tabular}{|c|c|c|c|c|c|c|c|c|}
\hline \multirow[b]{3}{*}{ Model } & \multicolumn{6}{|c|}{ Coefficients $^{\mathbf{a}}$} & & \\
\hline & \multicolumn{2}{|c|}{$\begin{array}{l}\text { Unstandardized } \\
\text { Coefficients }\end{array}$} & \multirow{2}{*}{$\begin{array}{c}\text { Standardized } \\
\text { Coefficients } \\
\text { Beta } \\
\end{array}$} & \multirow[b]{2}{*}{$\mathrm{t}$} & \multirow[b]{2}{*}{ Sig. } & \multirow{2}{*}{$\begin{array}{c}\text { Correlations } \\
\text { Partial }\end{array}$} & \multicolumn{2}{|c|}{$\begin{array}{c}\text { Collinearity } \\
\text { Statistics }\end{array}$} \\
\hline & $\mathrm{B}$ & Std. Error & & & & & Tolerance & VIF \\
\hline $\begin{array}{ll}\text { (Constant) } \\
\end{array}$ & 1.447 & .245 & & 5.909 & .000 & & & \\
\hline EQ & .201 & .087 & .225 & 2.323 & .022 & .341 & .634 & 1.578 \\
\hline IQ & .409 & .081 & .487 & 5.024 & .000 & .552 & .634 & 1.578 \\
\hline
\end{tabular}

a. Dependent Variable: KUALITAS MSDM

\section{Masa Pandemi Covid-19}

\begin{tabular}{|c|c|c|c|c|c|c|c|c|}
\hline \multicolumn{9}{|c|}{ Model Summary $^{\mathbf{b}}$} \\
\hline Model & $\mathrm{R}$ & R Square & \multicolumn{2}{|c|}{ Adjusted R Square } & \multicolumn{2}{|c|}{$\begin{array}{l}\text { Std. Error of the } \\
\text { Estimate }\end{array}$} & \multicolumn{2}{|c|}{ Durbin-Watson } \\
\hline 1 & $.703^{\mathrm{a}}$ & .494 & \multicolumn{2}{|c|}{.483} & \multicolumn{2}{|c|}{2.056} & \multicolumn{2}{|c|}{2.191} \\
\hline \multicolumn{9}{|c|}{$\begin{array}{l}\text { a. Predictors: (Constant), IQ, EQ } \\
\text { b. Dependent Variable: KUALITAS MSDM }\end{array}$} \\
\hline \multicolumn{9}{|c|}{ ANOVA $^{a}$} \\
\hline \multicolumn{2}{|r|}{ Model } & \multicolumn{2}{|c|}{ Sum of Squares } & df & Mean Square & & $\mathrm{F}$ & Sig. \\
\hline \multirow[t]{3}{*}{1} & Regression & 399.939 & & 2 & 199.969 & & .303 & $.000^{\mathrm{b}}$ \\
\hline & Residual & 410.061 & & 97 & 4.227 & & & \\
\hline & Total & 810.000 & & 99 & & & & \\
\hline
\end{tabular}

a. Dependent Variable: KUALITAS MSDM

b. Predictors: (Constant), IQ, EQ

\begin{tabular}{|c|c|c|c|c|c|c|c|c|c|}
\hline & \multicolumn{9}{|c|}{ Coefficients $^{a}$} \\
\hline & \multirow[b]{2}{*}{ Model } & \multicolumn{2}{|c|}{$\begin{array}{l}\text { Unstandardized } \\
\text { Coefficients }\end{array}$} & \multirow{2}{*}{$\begin{array}{c}\text { Standardized } \\
\text { Coefficients } \\
\text { Beta }\end{array}$} & \multirow[b]{2}{*}{$\mathrm{t}$} & \multirow[b]{2}{*}{ Sig. } & \multirow{2}{*}{$\begin{array}{l}\text { Correlations } \\
\text { Partial }\end{array}$} & \multicolumn{2}{|c|}{$\begin{array}{l}\text { Collinearity } \\
\text { Statistics }\end{array}$} \\
\hline & & $\mathrm{B}$ & Std. Error & & & & & Tolerance & VIF \\
\hline 1 & (Constant) & 18.344 & 2.513 & & 7.301 & .000 & & & \\
\hline & EQ & .023 & .018 & .091 & 1.258 & .211 & .127 & .993 & 1.007 \\
\hline & IQ & .340 & .036 & .689 & 9.510 & .000 & .695 & .993 & 1.007 \\
\hline
\end{tabular}

Sumber : SPSS Versi 25

Dari hasil SPSS ini dapat terlihat adanya perbedaan Kualitas Sumber Daya Manusia Pariwisata Pra/Sebelum dan Masa Pandemi Covid-19 di Objek Wisata Pantai Pangandaran.

1. Secara Simultan, pada Sebelum Pandemi besarnya pengaruh EQ dan IQ terhadap Kualitas SDM Pariwisata adalah sebesar $42,1 \%$, tingkat signifikan di bawah 0,05 , sehingga disimpulkan berpengaruh signifikan.

2. Sedangkan pada masa Pandemi Covid-19 besarnya pengaruh EQ dan IQ sebesar 49,4\% atau mengalami kenaikan sebesar 7,3\%, tingkat signifikan di bawah 0,05 , sehingga disimpulkan berpengaruh signifikan. Artinya ada selisih sebesar 7,3\% yang merupakan perbedaan atau efek dari Pandemi Covid-19 kepada pengaruh EQ dan IQ terhadap Kualitas SDM Pariwisata di Objek Wisata Pantai Pangandaran.

3. Secara Parsial, pada sebelum Pandemi Covid-19 besarnya pengaruh Kecerdasan Emosional terhadap Kualitas Sumber Daya Manusia sebesar 11,62\% $\left(0,341^{2} \times 100 \%\right)$, tingkat signifikan diatas 0,05 $(0,022<0,05)$ sehingga disimpulkan berpengaruh signifikan. Sedangkan pada Sebelum Pandemi Covid19 besarnya pengaruh Kecerdasan Intelektual terhadap Kualitas Sumber Daya Manusia sebesar $30,47 \%\left(0,552^{2} \times 100 \%\right)$, tingkat signifikan di bawah $0,05(0,000<0,05)$ sehingga disimpulkan berpengaruh signifikan.

4. Secara Parsial, pada masa Pandemi Covid-19 besarnya pengaruh Kecerdasan Emosional terhadap 
Arga Sutrisna dan Ari Arisman, Perbandingan: Kualitas Sumber Daya Manusia (SDM) Pariwisata Pra dan Masa Pandemi Covid-19 di Objek Wisata Pantai Pangandaran

Kualitas Sumber Daya Manusia sebesar 1,61\% $\left(0,127^{2} \times 100 \%\right)$, tingkat signifikan di atas 0,05 $(0,211<0,005)$ sehingga berpengaruh tetapi tidak signifikan. Sedangkan pada masa Pandemi Covid-19 besarnya pengaruh Kecerdasan Intelektual terhadap Kualitas Sumber Daya Manusia sebesar 48,3\% $\left(0,695^{2} \times 100 \%\right)$, tingkat signifikan di bawah 0,05 $(0,000<0,005)$ sehingga berpengaruh signifikan.

5. Secara parsial, terjadi penurunan pengaruh sebesar 10,01\% yang merupakan efek dari Pandemi Covid-19 kepada pengaruh EQ terhadap Kualitas SDM Pariwisata di Objek Wisata Pantai Pangandaran. Serta terjadi kenaikan pengaruh sebesar 17,83\% yang merupakan dampak Pandemi Covid-19 kepada pengaruh IQ terhadap Kualitas SDM Pariwisata di Objek Wisata Pantai Pangandaran.

\section{SIMPULAN}

Secara Simultan terdapat kenaikan pengaruh EQ dan IQ terhadap Kualiatas SDM Pariwisata. Namun Secara parsial, terjadi perubahan yang drastis pada variabel Kecerdasan Emosional, dimana mengalami penurunan pengaruh dan sebelum Pandemi Covid-19 berpengaruh Siginifikan menjadi berpengaruh tidak signifikan pada masa Pandemi Covid-19. Berbanding terbalik dengan variabel Kecerdasan Intelektual yang mengalami kenaikan pengaruh setelah ada Pandemi Covid-19 dan tetap berpengeruh signifikan.

\section{DAFTAR PUSTAKA}

Daniel Goleman, 2005, Emotional Intelligence, Jakarta: PT. Gramedia Pustaka Utama

Daniel Goleman, 2016. Emotional intelligence kecerdasan emosional mengapa el lebih penting dari pada iq. Jakarta: PT Gramedia Pustaka Utama

Eysenck, H. J. (1981). A model for personality. SpringerVerlag.

Matutina, Domi C. 2001. Manajemen Sumber Daya Manusia. Jakarta : PT.Gramedia Widia Sarana Indonesia.

Moustafa, K,S, and, Miller, T, R. 2003. Too Intelligent For The Job? The Validity of Upper Limit Cognitive Ability Test Scores In Selection. Sam Advanced Management Journal, Vol.68

Rachmawati, Ike Kusdyah. 2007. Manajemen Sumber Daya Manusia. Yogyakarta : CV Andi Offset. Retrieved from http://journal.stieken.ac.id/index.php/penataran/art icle/download/301/389

Rony Ika Setiawan (2016). Pengembangan Sumber Daya Manusia di Bidang Pariwisata: Perspektif Potensi Wisata Daerah Berkembang. Jurnal Penelitian Manajemen Terapan (PENATARAN) Vol. 1 No. 1 (2016) hlm.23-35. https://journal.stieken.ac.id/index.php/penataran/ar $\underline{\text { ticle/view/301/389 }}$
Sholeh A. Rahman dan Wahab, M. Abdul. 2004. Psikolog dalam Persfektif Islam. Jakarta :Kencana.

Sedarmayanti, 2012. Manajemen Sumber Daya Manusia. Jakarta : Refika Aditama Eresco. 